\title{
INTEGRASI PANCASILA DALAM PENDIDIKAN AKUNTANSI MELALUI PENDEKATAN DIALOGIS
}

\author{
Ari Kamayanti \\ Email: arikamayanti@ub.ac.id \\ Universitas Brawijaya, Jl. MT. Haryono 165, Malang
}

\begin{abstract}
The fact that accounting is very much related to numbers and quantification has placed accounting education in its objectivity, rasionalism and anthropocentrism entrapment. In order to break free from this entrapment, a dialogic approach which is a practice of a liberating accounting education can be utilized. This study was based on empirical research in a Business and Professional Ethic class as a mandatory course for accounting students for a semester. The study employed narrative dialogic approach as method. The result of the dialogic process is restoried for the readers to fully catch the spirit of emancipation. Evoking love to God, others, nation and universe, is the main key to liberate accounting education that will result in action with consciousness of accountants. This study hopes to give a portrait of how a lecturer could internalize holistic consciousness based on love in accounting education. In the end, it would take more than consciousness to mend accounting education, but also willingness.
\end{abstract}

Key words: action with consciousness, dialogic approach, ethics, love

\begin{abstract}
Abstrak
Fakta bahwa akuntansi sangat terkait erat dengan angka dan kuantifikasi telah meletakkan pendidikan akuntansi pada penjara obyektivitas, rasionalisme dan antroposentrisme. Dalam rangka membebaskan pendidikan akuntansi dari penjara ini, suatu pendekatan dialogis yang merupakan praktik pendidikan akuntansi yang membebaskan digunakan. Studi empiris dilakukan pada sebuah kelas untuk mata kuliah wajib Etika Bisnis dan Profesi selama satu semester. Studi ini menggunakan pendekatan naratif dialogis sebagai metode. Hasil proses dialogis diceritakan ulang agar pembaca dapat menangkap secara jelas semangat emansipasi. Membangun cinta pada Tuhan, lingkungan, negara, dan semesta menjadi kunci utama pembebas pendidikan akuntansi yang akan berdampak pada tindakan berkesadaran akuntan. Studi ini diharapkan dapat memberi gambaran bagaimana seorang pendidik dapat menginternalisasi kesadaran holistis berdasarkan cinta dalam pendidikan akuntansi. Pada akhirnya, dibutuhkan lebih dari sekadar kesadaran, namun juga kemauan untuk memperbaiki pendidikan akuntansi.
\end{abstract}

Kata kunci: tindakan berkesadaran, pendekatan dialogis, etika, cinta

Orang-orang kritis adalah orang yang penuh cinta, karena mereka tidak bisa diam ketika melihat adanya ketidakadilan

(Paulo Freire, 2001)

\section{Pendahuluan}

Pada Konferensi Nasional Pendidikan Akuntansi yang diadakan di Fakultas Ekonomi dan Bisnis di Universitas Brawijaya pada tanggal 18-20 April 2012 lalu, Pancasila menjadi bintang yang bersinar saat ia diletakkan secara konkrit pada landasan arsitektur pendidikan akuntansi Indonesia. Perilaku ber- 
panca-kesadaran menjadi hasil akhir pendidikan akuntansi Indonesia yang diharapkan. Panca kesadaran berasal dari lima nilai yang diabstraksi dari lima sila Pancasila, yaitu kesadaran ketuhanan, kemanusiaan, keIndonesiaan, kebersamaan dan keadilan.

Secara mulus ide peletakan Pancasila sebagai 'ruh' pendidikan akuntansi Indonesia diterima oleh semua tingkatan pendidikan akuntansi, mulai dari vokasi, pendidikan profesi, S1, S2 dan S3 baik akademik maupun terapan. Masalah timbul pada saat perumusan Learning Outcome (LO) pada setiap jenjang studi. Pertanyaan yang seringkali muncul diantara para pemerhati pendidikan akuntansi selama konferensi ini adalah: bagaimana mengukur LO seperti taqwa sebagai turunan dari kesadaran ketuhanan?

Bagi saya ${ }^{1}$, LO memang penting karena ia memberikan arahan tentang proses pendidikan, namun tidak demikian dengan pengukuran. Sebagaimana seorang dosen akan memberikan nilai 70, 80 atau 90 pada sebuah karya akhir mahasiswanya, perlu diingat dan direfleksikan bahwa subyektifitas akan selalu mengikuti proses penilaian yang bersifat kuantitatif tersebut, terlepas dari seberapa obyektif ia mengklaim dirinya. Menjadi absurd apabila suatu usulan proses pendidikan tidak dapat diterima hanya karena pengukurannya sulit dilakukan.

Pertanyaan yang seharusnya menjadi suatu poin kritis adalah apa implikasi logis dari peletakan Pancasila ke dalam pendidikan akuntansi. 'Ruh' kecintaan kepada Tuhan, kemanusiaan, keIndonesiaan, kebersamaan dan keadilan tentu akan memiliki konsekuensi mendasar pada materi akuntansi yang diajarkan (termasuk asumsi, tujuan dan praktik akuntansi), hingga pada proses pembelajaran. Perlu suatu telaah kritis tentang nilai-nilai yang dibawa akuntansi konvensional bahkan agenda-agenda penerapan suatu praktik akuntansi, termasuk etika yang harus disejajarkan dengan nilai-nilai ideologi bangsa.

Ludigdo dan Kamayanti (2012) sempat melakukan kritisi atas etika akuntansi yang tidak sesuai dengan ideologi Indonesia. Mereka mensinyalir bahwa terjadinya kegagalan dalam ranah etika akuntansi bisa jadi dikarenakan hilangnya akar dari etika itu sendiri yaitu ketuhanan yang merupakan dasar ideologi Indonesia. Kunci dari penyebaran etika adalah pendidikan, namun hal ini tidak akan dapat dilakukan maksimal apabila Pancasila telah sekadar menjadi retorika.

"Pancasila is only written in books, scientific studies, while the noble value has been abandoned. Pancasila has become mere rhetoric. Empirical finding show that in Indonesia, accounting education has become very objective, and is purposed to supply market with accountants as labours under corporate hegemony, as well as lacking spiritual values". (Ludigdo dan Kamayanti, 2012:162)

Sangat disayangkan pula, pendidikan akuntansi bisa dikatakan 'terpisah' dari substansi ketuhanan. Sebagaimana yang pernah dikonfirmasikan kepada salah seorang pengurus IAI-KAPd, pendidikan agama yang dimasukkan dalam kurikulum mengajarkan tata cara beribadah serta 'translasi' kitab suci (Kamayanti, 2012a). Seandainyapun terdapat pengajaran substansi, hal tersebut masih terpisah dengan akuntansi itu sendiri.

Jika kita masih mempercayai Pancasila, perlu dipertanyakan kembali bagaimana menginternalisasikan Pancasila untuk menghasilkan akuntan yang memiliki kesadaran yang utuh; kesadaran Pancasilais? Pancasila perlu diinternalisasikan karena ia tidak boleh menjadi sekedar retorika. Pendidikan akuntansi konvensional yang oleh beberapa, dianggap sebagai suatu alat untuk melakukan opresi (Oakes dan Berry, 2009) yang dilakukan sekedar untuk memenuhi kebutuhan korporasi (Mayper et. al, 2005) dan pasar (James, 2008) perlu dibebaskan. Irvin (1995) menegaskan bahwa inersia terhadap

1 Penggunaan kata 'saya' merupakan suatu kesengajaan untuk menekankan penggunaan subyektifitas pada penelitian ini. Keilmiahan suatu tulisan yang seringkali diindentikkan dengan obyektifitas dengan meletakkan peneliti sebagai orang ketiga dalam tulisan, merupakan karakter maskulin (Bourdieu, 2010). Dalam paradigma lain, keilmiahan dapat mengambil posisi subyektifitas yang sangat ekstrim sebagaimana yang dapat ditemui pada tradisi solipsisme (Burrell dan Morgan, 1979:239). 
perubahan pendidikan akuntansi sebagaimana yang dikompilasikan oleh the AAA's Bedford Committee diakibatkan antara lain oleh mahalnya perubahan, serta terlalu bergantungnya pendidikan akuntansi dengan buku-teks. Sejatinya, perubahan bentuk pendidikan akuntansi merupakan suatu proses emansipasi melalui dialog tanpa terjebak dalam kekakuan buku teks, termasuk pula internalisasi Pancasila dalam pendidikan akuntansi. Tulisan ini mengangkat proses pembebasan yang diambil dari pembelajaran nyata pada sebuah kelas Etika Bisnis dan Profesi bagi mahasiswa akuntansi selama satu semester di semester genap 2011-2012.

\section{Metode Penelitian}

Cerita tentang sebuah pembebasan yang akan disajikan berikut ini merupakan hasil empiris dialog dari suatu kelas Etika Bisnis dan Profesi di sebuah perguruan tinggi. Penelitian ini menggunakan data berupa proses pembelajaran (sebagian direkam dengan rekorder dan sebagian lainnya dalam bentuk hasil tugas mahasiswa) yang diambil dari beberapa pertemuan di kelas Etika Bisnis dan profesi yang terdiri dari 31 mahasiswa S1. Proses membangkitkan kesadaran ke dalam pendidikan akuntansi dan bagaimana suatu pendidikan dialogis yang berfokus pada kesadaran (consciousness) ditunjukkan melalui suatu cerita yang utuh.

Penentuan paradigma penelitian ini bukanlah hal penting. Walaupun demikian, ada asumsiasumsi ontologis yang melandasi alasan mengapa hasil penelitian ini ditulis dengan cara naratif. Pertama, pendidikan akuntansi merupakan suatu sarana transfer nilai peradaban (Al Attas, 1981:220-221) dan merupakan suatu alat untuk melakukan intervensi dengan cara yang paling lembut (subtle) (Held, 1980). Kedua, berbagai bentuk kesadaran secara simultan harus dibangkitkan untuk mendapatkan suatu manusia yang utuh (Kamayanti, 2012b). Berdasarkan hal tersebut, lima bentuk kesadaran Pancasila, yang merupakan nilai yang harus ditransfer dalam pendidikan pun harus dilakukan secara simultan, seperti sebuah ledakan big bang yang memancarkan cinta Tuhan dalam satu energi masif. Capra (2000:205) menjelaskan bahwa big bang terjadi saat "...partikel-partikel sub atomik bertumbukan satu sama lain...dengan kecepatan yang amat tinggi [kecepatan cahaya]". Pembangkitan kesadaran puncak semacam ini memerlukan suatu pembangkitan seluruh kesadaran secara bersamaan, bertumbukan dan berkembang menjadi ledakan pembebas yang besar (Kamayanti, 2012b).

Proses pembangkitan kesadaran tersebut menjadi kunci penting pendidikan yang membebaskan. Proses ini dilakukan dengan pendekatan dialogis. Pendidikan dialogis adalah pendidikan yang diusulkan oleh Freire (1972) sebagai pendidikan yang memiliki nilai cinta, kerendahan hati, harapan dan keyakinan. Namun jika Freire (1972) berhenti pada tataran cinta pada dunia, maka dalam penelitian ini, cinta tersebut diekstensikan menuju cinta pada Tuhan.

Berdasarkan asumsi-asumsi tersebut, maka hasil penelitian ini disusun dengan gaya narasi yang oleh Creswell (2007:55) yang memiliki fokus yang spesifik dan kontekstual. Gaya narasi dialogis semacam ini juga pernah dilakukan oleh Hines (1988) saat ia mencoba memberikan suatu pandangan kritis tentang realita dalam akuntansi. Gaya serupa pun juga diikuti oleh Sukoharsono (2011) dalam menjelaskan akuntansi lingkungan pada pembukaan Simposium Nasional Akuntansi (SNA) 14 Aceh. Namun, perbedaan mendasar antara kedua tulisan tersebut dengan penelitian ini terletak pada data trustworthiness yang menurut Patton (2005:50) merupakan suatu titik sentral otentisitas. Jika Hines (1988) dan Sukoharsono (2011) menggunakan dialog fiktif atau dalam bahasa Sukoharsono (2011) suatu imaginary neo-postmodernist dialogue, maka penelitian ini dibangun berdasarkan dialog empiris selama satu semester yang telah disusun ulang dan proses ini justru menjamin validitasnya sebagaimana dinyatakan oleh Kirk dan Miller (1986:32):

"...we have no other technology of making this kind of validity check than long-run personal interaction... a good rapport over a long period of time is the best check we can make”.

Penyusunan ulang hasil empiris menggunakan teknik yang disebut dengan restorying yang menurut Creswell (2007:56) merupakan: 
"...the process of reorganizing the stories into some general type of framework. This framework may consist of gathering stories, analyzing them for key elements of the story (e.g., time, place, plot and scene), and then rewriting the stories to place them within a chronological consequence."

Restorying dilakukan agar proses dialogis menunjukkan suatu cerita yang tidak terfragmentasi, namun utuh, untuk memberikan ide yang mengalir.

Dalam pendidikan dialogis, agar terjadi suatu emansipasi maka seorang dosen harus melakukan intervensi terhadap cara berpikir mahasiswa. Salah satu bentuk pendekatan yang memungkinkan hal ini terjadi adalah tradisi intervensionisme. Intervensi yang dilakukan oleh dosen khususnya saat mengarahkan mahasiswa untuk berpikir secara rasional, namun tetap kritis, serta menggunakan rasa/intuisi dan spiritualitas mereka tidak bisa dijabarkan dengan cara yang lebih baik dari pengungkapan dialogis. Intervensionisme adalah suatu jalan untuk mengubah tindakan (Jonsonn, 2010), termasuk memasukkan berbagai nilai dalam proses pembelajaran. Metode serupa pernah dilakukan oleh Kamayanti (2012b) saat melakukan pendekatan dramaturgi intervensionisme untuk melakukan perubahan dalam pendidikan akuntansi melalui dosen. Dalam intervensionisme, dosen berperan sebagai pihak yang melakukan persuasi, mendorong terjadinya emansipasi. Menurut Baskerville and Wood-Harper (1996:235), pendekatan intervensionisme dapat disejajarkan dengan action research:

"Action research is a method that could be described as a paragon of the post-positivist research methods. It is empirical, yet interpretive. It is experimental, yet multivariate. It is observational, yet interventionist. Enticingly, the research subjects are often quite willing to pay the costs of being studied, especially since they may influence the outcomes of the project. To an arch positivist it should seem very unscientific. To the postpositivist, it seems ideal."

Oleh karena itu, dalam rangka menunjukkan aliran dialogis, penulisan cerita akan banyak menggunakan footnote untuk menunjukkan dukungan pernyataan melalui scientific justification tanpa harus meninggalkan trustworthiness tidak hanya dari data namun juga pengungkapannya. Hasil penelitian ini ditulis dalam bentuk cerita tentang sebuah proses pembebasan.

\section{Hasil dan Pembahasan}

"Wah, Ibu marah," kata seorang mahasiswa lirih.

"Tentu saja saya sedang marah!” sahut saya tegas. Kelas menjadi sunyi dan semua mata tertuju pada saya. Para mahasiswa menunggu dengan antisipasi terhadap apa yang akan saya ucapkan. Kami sedang membahas tentang keterkaitan antara ideologi yang menjadi dasar nilai etis hidup dengan akuntansi sebagai wujud tindakan atas nilai yang dianut tersebut. Saya baru saja membahas secara berapi-api tentang anggaran untuk pesawat terbang presiden, kursi rapat anggota dewan serta au contraire kisah anak-anak yang harus menyebrangi sebuah sungai di atas seutas tali untuk menuju sekolah.

"Saya marah terhadap kondisi bangsa kita saat ini. Saya marah atas keterbatasan saya untuk dapat melakukan perubahan yang berarti. Saya marah atas ketidaksadaran sebagian besar dari kita tentang perilaku kita, perilaku bangsa. Bukankah telah kita bahas tentang bagaimana Pancasila dan UUD 1945 merupakan nilai kita yang seharusmya memunculkan perilaku bangsa, namun ternyata tidak. Bukankan kalian setuju bahwa apa yang kalian lakukan sebenarnya berdasar pada nilai etis ${ }^{2}$ yang kalian anut?" suara

2 Etika atau "ethos" tidak hanya menyiratkan karakter yang mengakibatkan terjadinya perilaku etis. Ia memiliki empat dimensi yaitu (1) apa yang menjadikan diri sebagai "diri"; (2) lingkungan sosial (termasuk pendidikan); (3) apa yang terjadi pada diri dalam berbagai 
saya bereskalasi dan saya beranjak dari kursi untuk berdiri di tengah 31 mahasiswa. Mereka duduk diam, menatap saya. Tubuh mereka yang duduk condong ke depan menunjukkan minat dan kefokusan mereka dalam diskusi pagi itu. Saya biarkan jeda waktu meresapkan pertanyaan mendasar tentang keterkaitan antara etika dan perilaku.

"Fira mengapa kau datang ke kampus berpakaian hari ini?", dengan nada yang lebih datar saya menunjuk seorang mahasiswi yang berjilbab. Keheningan mencair mendengar pertanyaan tersebut. Fira tersenyum, "Masak, tidak berpakaian, Bu. Kan malu nanti."

"Bagus," sahut saya, "Malu! Malu karena jika Fira tidak berpakaian maka tidak sesuai dengan apa yang Fira percayai dan yakini. Jangankan tidak berpakaian. Apabila saya minta Fira melepaskan jilbabnya sekarang, ia juga pasti tidak mau karena malu, bukan?". Fira mengangguk setuju. "Artinya nilai Islam, dalam kasus Fira, menjadi nilai etis yang akan tercermin dalam kehidupannya. Mengapa kalian semua datang ke kelas pagi ini juga pasti didasari oleh suatu nilai yang kalian yakini benar. Baik itu untuk membahagiakan orang tua, menuntut ilmu atau hidup mandiri kelak di kemudian hari. Apakah kalian setuju tentang pernyataan saya ini?" Mahasiwa mengangguk dan diskusi berlanjut lagi.

"Mari kita jenguk kembali nilai etis bangsa kita, yang masih kita yakini bersama, yaitu Pancasila serta UUD 45. Kita ambil salah satu nilai, misalnya, apa sila pertama?"

"Ketuhanan yang Maha Esa", beberapa mahasiswa menjawab.

"Baik. Apakah akuntansi sebagai hasil dari perilaku bangsa telah mencerminkan nilai etis sila pertama tersebut yang dianut Indonesia?". Sejenak kelas sunyi kembali untuk berpikir.

"Kalau pakai sila pertama ya harusnya laporan keuangan pakai macam bismillahirrahmanirrahiim atau dengan nama Tuhan gitu, Bu", Hani, seorang mahasiswi menjawab. Beberapa mahasiswa yang lain tertawa.

"Mengapa Ramdy tertawa?" tanya saya menunjuk seorang mahasiswa yang masih tertawa sambil menutup wajahnya.

"Ya aneh dong Bu. Masak bawa nama Tuhan segala dalam akuntansi. Ya benernya gak perlu. Setiap manusia itu memiliki kepercayaan terhadap Tuhan. Tidak perlu di...apa namanya...eksplisitkan [kelas berdecak menggoda saat kosa kata ini muncul]. Kan gak harus demikian, semua orang pasti percaya Tuhan sesuai agamanya masing-masing"

"Hmm... pemikiran yang menarik. Apakah kalian setuju?" sebagian mengangguk dan sebagian menggeleng. Saya melanjutkan, "katakan saja... kita akan mengadakan suatu rekreasi bersama. Semua orang yang akan ikut pada rekreasi itu akan dicatat namanya. Ramdy tidak tercatat padahal dia ikut dalam rekreasi itu." Mahasiswa yang sedang dibicarakan tersenyum. "Kita akan katakan pada Ramdy, bahwa tidaklah penting namanya dicatat, karena toh semua sudah tahu bahwa Ramdy pasti ikut, karena Ramdy ada di hati kita," lanjut saya tersenyum. Saya menegaskan kalimat "di hati kita" dengan ekspresi gerak ala girl-band yang sedang marak di Indonesia. Kelaspun tertawa. "Bagaimana Ramdy? Bagaimana perasaanmu sekarang?"

Sang empunya nama hanya tertawa lirih

"Artinya," jelas saya, "saat sesuatu hilang dari teks, maka sebenarnya sesuatu tersebut secara sadar ternegasikan ${ }^{3}$ atau terpinggirkan. Ramdy saja merasa ternegasikan. Ini kita bicara Tuhan. Berani kalian menegasikan Tuhan secara sadar dalam Laporan Keuangan? Berani sungguh?"

"Jika demikian," sambung Hani, "mengapa kita tidak menuliskan nama Tuhan saja di Laporan Keuangan?"

"Aha... sebenarnya Luca Pacioli" menuliskan In the Name of God saat ia membuat laporan keuangan. Pertanyaan Hani tadi sebenarnya sangat berkaitan dengan nilai yang kita anut. Nilai

kejadian (mungkin bisa pula diasumsikan sebagai pengalaman), dan (4) keinginan individu (Kikerby, 2005)

${ }^{3}$ Cavallaro (2004:138) menjelaskan bahwa suatu teks merupakan hasil dari suatu dominasi pemikiran tertentu. Dalam kaitan dengan nama Tuhan yang bahkan tidak tersentuh di buku teks akuntansi, maka Tuhan telah sebenarnya terdominasi dan terpinggirkan dalam akuntansi. 
ketuhanan sudah tidak lagi menjadi sumber ilmu pengetahuan. Mengapa demikian? Jawabannya adalah karena Tuhan dianggap tidak bisa dibuktikan secara empiris. Tuhan ada pada rasa dan keyakinan. Rasa tidak bisa dibuktikan secara empiris karena rasa dan demikian pula Tuhan bersifat subyektif dan terkait dengan individual. Ilmu sudah terkungkung pada kebenaran bahwa ia harus obyektif. Obyektivitas merupakan suatu karakter yang maskulin ${ }^{5}$, sedangkan rasa di sisi lain sesuatu yang subyektif. Ilmu akuntansi juga tak lepas dari kebenaran tersebut," saya memberikan gesture tanda kutip dengan tangan pada 'kebenaran'. "Inilah suatu bentuk sekularisasi ${ }^{6}$ ilmu yaitu pemisahan Tuhan dan segala hal yang bersifat duniawi, termasuk ilmu akuntansi ${ }^{7}$. Siapa yang kira-kira berani menulis skripsi tentang misalnya kasih sayang atau cinta dalam akuntansi?" Mahasiswa tertawa sambil menggeleng tidak ragu. "Takut ditertawakan ya? Kalian tahu mengapa? Ini dikarenakan adanya pertanyaan mendasar tentang keilmiahan. Apakah 'ilmiah' suatu tulisan tentang kasih sayang atau cinta atau keindahan? Ini juga merupakan suatu bukti tentang kesadaran kita, kesadaran, kalian bahwa hal-hal yang sedemikian bukan merupakan ilmu yang bisa diterima. Mau bukti lain? Siapa yang pernah melihat kata Tuhan dalam buku teks akuntansi yang kalian baca?" Para mahasiswa menggeleng sambil tertawa. "Siapa dosen yang kalian tahu yang bicara Tuhan dalam akuntansi?"

"Hanya satu dua orang saja, Bu. Mmm... Akuntansi Syariah bicara Tuhan," tegas seorang mahasiswa setelah sejenak hening.

"Benar! Mengapa Akuntansi Syariah bicara tentang Tuhan? Karena nilai etis yang dianut adalah Tuhan, Tauhid ${ }^{8}$. Akuntansi Syariah muncul karena kegundahan atas akuntansi konvensional yang materialistis, kapitalistis. Nilai etis yang berbeda akan menghasilkan ilmu yang berbeda, perilaku yang berbeda pula. Nilai-nilai dalam akuntansi konvensional telah membentuk kalian melalui pendidikan akuntansi sebagai sarana petransferan nilai. Selama enam semester pikiran kalian telah dicekoki oleh ilmu yang sedemikian rupa dan membentuk perilaku kalian. Coba sebutkan Laporan Keuangan yang menurut kalian paling penting."

"Laporan Laba Rugi!" seru mayoritas mahasiswa.

${ }^{4}$ Luca Pacioli adalah seorang rahib yang menggagas ide double-entry dalam akuntansi yang ia tulis 150 tahunan setelah praktik tersebut ditemukan di Italia bagian utara. Ia menuliskan kalimat pembuka dengan nama Tuhan. Walaupun Derks (2008) percaya bahwa ada kemungkinan Barat belajar tata buku/akuntansi dari Arab, namun Luca Pacioli-lah yang lebih terkenal sebagai Bapak Akuntansi.

${ }^{5}$ Maskulinitas akuntansi sudah sering menjadi bahasan (Hines, 1992; Triyuwono, 2010) yaitu obyektivitas yang mengeliminasi secara berlebih subyektivitas. Keberadaan maskulinitas dalam pendidikan akuntansi di Indonesia pada umumnya secara empiris telah dibuktikan oleh Kamayanti (2012a); serta Setiawan dan Kamayanti (2012) saat menengok praktik pembelajaran Fraud Accounting di Universitas Trunojoyo Madura.

6 Al Attas (1981:20-21) menjelasan bahwa sekularisasi terdiri dari tiga elemen yaitu disenchantment of nature, desacralization of politics dan deconsecration of values. Kesemuanya merupakan pemisahan antara Tuhan dengan manusia, alam dan nilai. Lebih lanjut, Glasner (1992:65) menjelaskan bahwa pemisahan ini terjadi karena pemikiran tentang Tuhan merupakan pemikiran ilusional yang rendah, yang dalam prosesnya akan berevolusi menjadi pemikiran rasional pada tingkatan tertinggi.

7 Akuntansi yang sekuler dan konsekuensinya pendidikan akuntansi yang sekuler dibahas oleh Mulawarman (2008). Kunci untuk melakukan desekularisasi menurutnya adalah melalui pensucian atau tazkiyah. Kamayanti (2012a) mengelaborasi desekularisasi pendidikan akuntansi dengan menggunakan ekstensi metodologi dialogis dari Paulo Freire (1972).

${ }^{8}$ Mulawarman (2009) dan Triyuwono (2006) menjelaskan tentang nilai Tauhid yang melandasi Akuntansi Syariah. 
"Benar kan...”, lanjut saya terkekeh, "Mengapa Laba Rugi menjadi urutan pertama dalam kesadaran kalian? Ini karena selama enam semester, kalian sudah dicuci otak dengan nilai-nilai tersebut. Laba menjadi hal yang sangat penting karena dengan laba, kapital akan bertambah. Bentuk laporan Laba Rugi telah mendorong kita untuk menjadi manusia penumpuk kapital. Itulah manusia-manusia kapitalis. Jadi apakah kemudian salah jika akuntansi yang ada saat ini merupakan alat pelanggeng kapitalisme ${ }^{10}$ ? Padahal, sebenarnya seluruh laporan keuangan akan menjadi jelas dengan adanya Catatan atas Laporan Keuangan (CALK). Namun, tidak satupun dari kalian yang menjawab CALK penting. Jadi kalau kita mau menunjuk, siapa yang bersalah dalam hal ini?"

"Dosen ya Bu", timpal Sari pelan sambil memandang malu, "Maaf ya, Bu". Beberapa mahasiswa melontarkan godaan-godaan kecil "hayoo..." saat mendengar ungkapan Sari.

"Ya, Sari benar! Dosen. Dosen yang bersalah" karena mereka membiarkan transfer ilmu yang sedemikian rupa. Oleh karena itulah saya di sini untuk memberikan pandangan lain tentang akuntansi. Tentu saja, pada akhirnya kalianlah yang akan memberikan keputusan tentang nilai etis apa yang akan kalian ikuti." Setelah jeda sebentar saya melanjutkan, "Mari kita lanjutkan diskusi tentang Tuhan dan akuntansi. Mari kita lanjutkan dengan nilai etis akuntansi. Jadi bagi kalian, apakah akuntansi Indonesia kita sekarang sudah Pancasilais? Pertanyaan ini saya sampaikan tentu dengan asumsi bahwa kita masih percaya bahwa Pancasila masih kita yakini benar sebagai ideologi atau sumber nilai etis kita. Masih percaya pada Pancasila?"

"Masiiiiih," kata kelas serempak.

"Baik... siapa yang mau memulai?"

Setelah diam sejenak, Hendra mengacungkan tangannya.

"Hmmm... begini Bu... saya rasa akuntansi kita belum Pancasilais. Mengapa demikian? Ini dikarenakan akuntansi kita masih mementingkan kepuasan pemegang saham, karena berorientasi pada laba. Laba pada akhirnya akan dibagikan pada pemegang saham dan muncul sebagai Earning per Share," Kelas berdecak menggoda lagi saat Hendra menyebutkan EPS. "Sebentar..sebentar...," lanjut Hendra menenangkan sok dewasa, yang justru semakin membuat kelas bergemuruh, "padahal sila kelima itu bicara tentang keadilan sosial bagi seluruh rakyat Indonesia. Kalau EPS kan tentang perusahaan dan para pemegang sahamnya. Artinya ini sangat egois. Laa ini kan berarti gak Pancasilais, Bu. Benar kan, Bu."

"Bagaimana menurut teman-teman? Apakah kalian sependapat?" tanya saya setelah tawa kelas mereda. Sebagian besar mahasiswa mengangguk mendengar pertanyaan saya. "Baik, akuntansi yang sangat berorientasi pada laba merupakan hal yang tidak Pancasilais karena tidak mencerrminkan keadilan sosial bagi seluruh rakyat Indonesia. Kita setuju dengan hal ini? Artinya akuntansi tidak hanya sebatas alat pelaporan? Akuntansi tidak tergantung pada pemakainya? Akuntansi tidak bebas nilai tetapi ia memiliki nilai yang ia bawa ${ }^{12}$ ?" para mahasiswa mengangguk setuju, "jika demikian, berarti kita semua

9 Indoktrinasi adalah penggunaan metode yang sama secara berulang-ulang untuk menanamkan ide (Peterson 2007).

10 Weber menjelaskan bahwa etika protestan telah membawa semangat kapitalisme yang telah diartikulasikan oleh akuntansi melalui rasionalisasi tindakan ekonomis (Christie et al. 2004). Sombart lebih lanjut menegaskan bahwa Yahudi telah berhasil menggunakan akuntansi moderen untuk mengakumulasi kekayaan. Menurut Sombart akuntansi memiliki semangat Yahudi (Funnel, 2005).

11 Ungkapan "Bertobatlah dosen-dosen Ekonomi" pernah terlontar dari Prof. Suherman Rosyidi saat berbicara tentang kurikulum ekonomi Islam mewakili Masyarakat Ekonomi Syariah (MES) di IAIN Sunan Ampel Surabaya, 2008.

12 Beberapa pendapat mengakui akuntansi sebagai suatu ilmu yang bebas nilai (value-free). Salah satunya ditegaskan oleh Truan dan Hughes (1999:27): "Accounting theory is based on the 
telah lepas dari pemikiran naif bahwa akuntansi bebas nilai. Artinya kalian sudah sangat paham tentang keterkaitan nilai etis, ilmu dan perilaku. Begitu pula di akuntansi. Nah, bagaimana ini jika akuntansi kita, akuntansi Indonesia, tidak sesuai dengan nilai yang kita sebagai bangsa Indonesia anut?"

"Hehe... Itu namanya munafik, Bu." Damian berteriak lantang.

"Bukan saya lho yang ngomong," saya menimpali ringan, "Dan kalau kesimpulanmu demikian, Damian, berarti kita semua munafik karena kita membiarkan suatu tindakan tidak sejalan dengan nilai yang kita yakini. Kita telah melakukan tindakan, dalam hal ini mempraktikkan akuntasi, tanpa kesadaran penuh, karena orang yang sadar adalah orang yang hati dan otaknya sejalan. Antara nilai dan tindakan tersinkronisasi."

"Wah, kalau tidak sadar artinya bisa sedang pingsan atau gila, Bu." Celoteh Damian disambut dengan tawa seluruh kelas.

"Hmm... apakah kalian sedang sadar?", tanya saya. Damian langsung menjawab lantang tentu saja sadar. Sejenak kemudian saya melanjutkan, "Tadi kita membahas bahwa selain akuntansi tidak Pancasilais, dosennya pun jarang yang membicarakan Tuhan, keadilan atau cerminan sila lain. Dosennya... hmm... juga tidak Pancasilais, ya?" Mahasiswa tergelak saat saya mengerling dengan pertanyaan terakhir itu. "Baik, kalau begitu pertanyaan saya pada kalian adalah apakah kalian merasa terganggu dengan akuntansi semacam itu atau dosen yang mengajar dengan cara demikian itu?"

Hani menjawab, "Biasa saja sih, Bu." Mahasiswa yang lain juga bergumam bahwa tidak ada masalah. Sesaat kelas menjadi kembali riuh saat mahasiswa saling mendiskusikan pertanyaan tersebut.

"Hehehe...jadi kalau boleh saya simpulkan, kita semua setuju bahwa akuntansi tidak Pancasilais, namun saat kita dihadapkan pada praktik semacam itu, praktik yang tidak Pancasilais, maka kita tidak ada masalah." Saya memberikan sedikit jeda setelah perlahan memberikan penekanan pada kalimat tersebut. "Hmm... begini, seandainya kalian yang muslim tidak saya perbolehkan sholat. Sama sekali tidak boleh. Apakah kalian akan merasa terganggu?", kelas mendengarkan dengan seksama. "Apakah kalian akan tetap sholat?"

Gagah menjawab, "Tentu saja saya merasa terganggu dan tentu saya akan tetap sholat."

"Ooo.. mengapa demikian?", lanjut saya. "Hal ini karena kalian yakin bahwa sholat itu wajib hukumnya, atas dasar perintah agama. Islam, dalam hal ini menjadi suatu pijakan nilai etis. Sholat adalah perilaku etis karena sesuai dengan nilai etis yang kalian percayai yaitu Islam." Beberapa mahasiswa mengernyitkan dahi mereka. "Sehingga," saya tambahkan, "kalian akan dan pasti benar-benar terganggu jika saya katakan pada kalian bahwa sholat dilarang. Itu karena kalian benar-benar percaya akan Islam sebagai nilai etis. Hehehe...jadi kalau kalian tidak terganggu dengan akuntansi yang diajarkan, yang sebagaimana kalian simpulkan sendiri, tidak sesuai dengan Pancasila, yang kita sebagai bangsa Indonesia percayai, apa artinya?". Beberapa mahasiswa tersenyum kecut dan beberapa terlihat resah dengan arah diskusi ini. Saya lanjutkan dengan nada keras, "Itu artinya kalian semua tidak percaya tentang kebenaran Pancasila. Kalian tidak percaya bahwa Tuhan perlu dalam akuntansi, bahwa kemanusiaan, keIndonesiaan, kebersamaan dan keadilan benar-benar dibutuhkan akuntansi. Itu adalah kesadaran kalian ${ }^{13}$. Itulah sebabnya kalian tidak merasa terganggu dengan akuntansi yang diajarkan pada kalian. Jadi sebenarnya kita hanya meletakkan lambang negara tersebut di kantor-kantor, gedung sekolah atau universitas sebagai hiasan. Tidak lebih!”.

assumption of value-free objectivity and empirical observation and the supposition that this way of knowing is superior to other more normative (subjective) ways of searching for truth."

${ }^{13}$ Oleh Freire (1972), kesadaran seperti ini disebut dengan naive consciousness. Suatu proses pembebasan memerlukan suatu penegasan pada yang terjajah bahwa memang telah terjadi proses pejajahan. Hanya saat hal ini terjadi, maka seseorang dapat bergerak dari naive consciousness menuju critical consciousness. 
Setelah menarik nafas panjang, saya melanjutkan, "Ini baru sebuah kelas yang terdiri dari 31 mahasiswa. Apakah kesadaran yang sama juga dimiliki para pemuda-pemudi bangsa kita ini? Saya sungguh kuatir dan takut untuk membayangkan betapa tidak sadarnya kita ini sekarang." Setelah meminum seteguk air saya melanjutkan. "Baik, mari kita mengintrospeksi kesadaran kita dalam berakuntansi. Mengapa IFRS sebagai satu standar tunggal menjadi penting? Agar laporan keuangan negara bisa diperbandingkan. Bukankah keseragaman standar meningkatkan daya banding? Pertanyaan berikutnya, siapa yang ingin membandingkan laporan keuangan dari berbagai negara? Jawabannya tentu investor kelas kakap yang memang ingin melakukan investasi yang tidak hanya menguntungkan tetapi bersifat menguasai. Didukung oleh deregulasi sebagai alat pembongkar batasan maka investor berhak masuk dan menguasai sumber daya alam. Inilah fenomena pasar bebas sekarang." Saya mengambil jeda dan menunjukkan sebuah artikel dari Republika ${ }^{14}$."Mari kita membaca dunia ${ }^{15}$. Mari kita diskusikan tentang migas Indonesia. Betapa kayanya Indonesia dengan hasil bumi termasuk minyak, namun mengapa rakyat Indonesia pemilik kekayaan harus membayar BBM dan justru akan dicabut pula subsidinya yang akan membuat harga BBM semakin mahal? Kemunculan Caltex, Shell dan distributor BBM lain di negara kita saat ini bukti bahwa bahkan migas telah jatuh dalam pelukan pasar bebas. Maka sungguh menyedihkan bahwa UUD 45 telah hilang relevansinya. Pasal $33^{16}$ tentang penguasaan kekayaan Indonesia yang akan mempengaruhi hajat hidup orang banyak pada negara jelas tidak lagi diaplikasikan. Lalu apa gunanya Pancasila dan UUD 45 apabila kita tidak lagi mempercayai kebenarannya?" Saya menarik nafas panjang setelah penjelasan yang panjang lebar dan berapi-api tadi. "Jadi...," lanjut saya, "Jika akuntansi saat ini adalah ilmu yang tidak sesuai nilai etis yang dianut Indonesia, maka akuntansi saat ini...?"

"Tidak etiiiiiiiiiis," sambung mahasiswa.

"Hmm... kalian semua tho ya, yang bilang demikian," sahut saya sambil tersenyum, "tidak etis menurut Pancasila, tetapi etis menurut pasar bebas? Adakah peran akuntansi di sini? Jika ada, apa peran akuntansi?"

"Ya... akuntansi memberikan informasi sebagai pengambilan keputusan, Bu," jawab Gagah.

"Hanya itu? Bagaimana dengan akuntansi etis Pancasilais dan akuntansi non-etis, non Pancasilais"?, kejar saya.

"Akuntansi Pancasilais harusnya bisa memberikan informasi apakah sudah perusahaan sudah adil, tidak hanya berpusat pada laba", lanjut Gagah.

"Artinya," saya menanggapi, "kalau akuntansi, seperti yang kalian katakan, tidak etis, maka akuntansi harus diubah. Ini merupakan tindakan berkesadaran. Sadar bahwa ada nilai etis yang melekat pada setiap tindakan begitu pula dengan akuntansi. Ini juga menunjukkan keberpihakan kepentingan. Kalian lebih mementingkan Caltex, Shell atau MNC lain yang sedang menguasai negara kita dengan mengaplikasikan akuntansi yang pro-kapitalis? Atau kalian mementingkan rakyat yang berteriak meminta kesejahteraan hidup dari pemerintah melalui akuntansi yang Pancasilais?" Kelas hening sejenak. "Jadi, mau pilih yang mana?"

14 Dari www.republika.co.id tanggal 30 Maret 2012 terdapat sebuah artikel tentang pemrotesan kenaikan BBM oleh 300 pedagang pasar di Semarang yang menyurati Presiden Soesilo Bambang Yudhoyono untuk tidak mencabut subsidi."

15 Membaca dunia adalah ungkapan yang diusulkan oleh Freire (1972) yang menekankan pentingnya pembacaan terhadap realita yang mengopresi untuk melakukan pembebasan.

16 Pasal 33 UUD 45 terdiri dari 3 ayat yaitu: (1) Perekonomian disusun sebagai usaha bersama berdasar atas azas kekeluargaan. (2) Cabang-cabang produksi yang penting bagi Negara dan yang menguasai hajat hidup orang banyak dikuasai hajat hidup orang banyak dikuasai oleh Negara. (3) Bumi dan air dan kekayaan alam yang terkandung di dalamnya dikuasai oleh Negara dan dipergunakan untuk sebesar-besarnya kemakmuran rakyat. 
Puput yang duduk diam sedari tadi akhirnya mengacungkan tangannya ingin bertanya. Dengan gerakan kepala saya mempersilakannya. "Tapi kita kan sudah punya standar akuntansi yang jelas, Bu. Mau diubah juga gimana caranya?", tanya Puput.

"Pertanyaan yang sangat menarik, Put. Saya juga sangat suka dengan pertanyaanmu karena sudah ingin tahu bagaimana cara mengubah. Artinya, kita sudah masuk ke paradigma kritis ${ }^{17}$. Coba kita tilik kembali apa yang dulu terjadi tanggal 17 Agustus 1945. Kita sedang dijajah saat itu, namun dengan lantang kita tidak peduli dengan ikatan penjajahan serta memproklamirkan kemerdekaan diri Indonesia. Cinta kepada keadilan, kemerdekaan yang merupakan wujud atas cinta kepada Tuhan adalah pembebas dari segala bentuk ikatan penjajahan. Apa bedanya ikatan penjajahan dengan standar akuntansi yang sudah ada? Sama-sama mengikat bukan? Seandainya saat itu Soekarno dan Hatta tidak melakukan proklamasi mungkin kita masih dalam jajahan Belanda."

"Bu, berarti kita sekarang dijajah dong?"

"Bagaimana menurutmu? Penjajahan ${ }^{18}$ secara fisik mungkin tidak. Namun ikatan standar akuntansi kita yang mengacu pada IFRS (International Financial Reporting Standards) dan ikatan pengadaan pendidikan akuntansi yang mengacu pada IES (International Education Standards) yang pada akhirnya akan tertuang pada Standar Pendidikan Akuntansi Indonesia (SPAI), sesuai kesepakatan kita memenuhi kewajiban anggota IFAC (International Federation of Accountant) ${ }^{19}$ bisa jadi adalah penjajahan model baru. Mengapa demikian? IFRS adalah untuk investor dan pasar modal saja ${ }^{20}$. Jadi kita memang hidup in this tangled web: jaring yang begitu rumitnya membelenggu kebebasan bangsa. Ironisnya, semua standar ini seakan datang untuk melakukan misi Save and Rescue (SAR). Standar tunggal dianggap sangat memberikan kebebasan dan hak bagi manusia untuk menjadi sejahtera ${ }^{21}$. Sayangnya, satu-satunya kebebasan yang diperoleh sebenarnya adalah kebebasan perdagangan. Suatu

17 Chua (1986) menjelaskan tentang perspektif dalam penelitian akuntansi, salah satunya perspektif kritis yang bertujuan melakukan emansipasi/pembebasan.

18 Akuntansi sebagai alat kolonisasi atau imperialisme dijelaskan oleh Oakes dan Berry (1999) serta Abeysekara (2005).

19 Terdapat 8 Statement of Member Obligations (SMOs) sebagai konsekuensi keanggotaan Ikatan Akuntan Indonesia (IAI) dalam International Federation of Accountant (IFAC). Salah satunya, SMO nomor 2 tentang standar pendidikan akuntansi negara anggota yang mengikuti International Education Standards (IES).

${ }^{20}$ Ratnatunga (2010) di sebuah konsorsium akuntansi internasional di Bali menjelaskan bahwa IFRS merupakan alat korporasi multi-nasional untuk lebih memudahkan mereka mengambil keputusan investasi. Pada kesempatan yang sama, Shalul Hameed, menegaskan keputusan untuk mengambil IFRS sebagai standar akuntansi suatu negara seringkali mengabaikan kepentingan lokal negara tersebut. Benar adanya bahwa perusahaan kecil dan menengah (SME) dapat menggunakan IFRS for SME atau di Indonesia SAK-ETAP (Standar Akuntansi Keuangan untuk Entitas Tanpa Akuntabilitas Publik), namun sebagaimana yang ditekankan oleh Kusuma (2007) mayoritas perusahaan di Indonesia yang merupakan SME membuat pengaplikasian SME menjadi mahal. Lebih lanjut ia menegaskan bahwa pengadopsian suatu standar yang bukan dibangun dengan melihat kondisi diri sendiri akan menghasilkan secondbest standards. Secara lebih tegas Mulawarman (2012) menyatakan bahwa apabila IFRS tidak mampu mengakomodasi kepentingan Indonesia maka tidak perlu ragu untuk menyampaikan apa yang pernah dilontarkan oleh Presiden Soekarno "Go to hell with your aid" dengan "Go to hell with IFRS".

${ }^{21}$ Penelitian menunjukkan bahwa tidak ada hubungan yang signifikan antara tingkat investasi asing dengan kemajuan kinerja HAM (Hertz, 2011). Artinya alih-alih perdagangan bebas merupakan sekedar angin surga apalagi bagi negara berkembang yang belum memiliki SDM dan teknologi yang cukup kuat. 
kondisi yang kita sebut sebagai neo-liberalisme. Bahkan ketika standar pendidikan kita pun harus mengikuti pola yang ditetapkan oleh badan internasional, siapa yang mempertanyakan mengapa dan untuk siapa? Jika akuntansi yang sekarang adalah untuk kepentingan MNC, maka pendidikan akuntansi juga didesain untuk kepentingan MNC. Kalian diciptakan untuk menjadi kuli-kuli MNC, komprador $^{22}$ negara". Kalimat yang terakhir saya ucapkan sambil tertawa.

"Jadi kita bisa apa, Bu?" tanya Hendra.

"Kalian bisa mencipta! Bukan berarti kemudian kalian tidak mau lagi belajar akuntansi. Itu pemikiran yang salah besar. Akuntansi yang sekarang harus dipelajari untuk kemudian dikritisi dan diperbaiki sesuai nilai etis. Kalian harus menguasai akuntansi utuk dapat mengetahui apa yang salah di akuntansi. Jika kalian bertanya apa yang bisa kalian lakukan maka kalian telah meng-underestimate diri sendiri. Saya dapat tunjukkan daya cipta kalian yang luar biasa yang mungkin kalian sendiri tidak sadari. Daya cipta itu berasal dari cinta." Mahasiswa bersoloroh "weee..." saat saya menekankan kata cinta. "Jadi jika akuntansi yang sekarang sangat cinta pada laba, maka ada aspek cinta lain yang belum ditangkap dalam akuntansi. Sekarang saya akan memutarkan sebuah video tentang cinta. Saya minta kalian membuka diri terhadap rasa. Apapun rasa yang hadir jangan ditolak. Terima dan nikmati! Jangan malu untuk menerima rasa karena sebenarnya kita terlalu lama telah dikuasai oleh obyektifitas. Kali ini biarkan subyektifitas masuk ke diri kalian."

Video berdurasi lebih kurang 5 menit tersebut adalah video yang saya ambil dari youtube dengan judul Sepucuk Surat dari Ibu dan Ayah. Isi video tersebut adalah rangkaian puisi yang diiringi lagu lembut dan foto-foto tentang kasih sayang anak dan orang tua. Adapun puisi yang ditampilkan adalah sebagai berikut:

Sepucuk surat dari Ibu dan Ayah

Anakku...

Ketika aku semakin tua, kuharap kau memiliki kesabaran untukku

Suatu ketika aku memecahkan piring,

Atau menumpahkan sup di atas meja karena penglihatanku berkurang,

Aku harap kau tidak memarahiku,

Orang tua itu sensitif,

Selalu merasa bersalah bila kamu berteriak,

Ketika pendengaranku memburuk dan aku tidak bisa mendengar apa yang kau katakan,

Aku harap kau tidak memanggilku tuli,

Mohon ulangi apa yang kau katakan atau menuliskannya,

Maaf anakku,

Aku semakin tua,

Ketika lututku semakin melemah,

aku harap kau memiliki kesabaran untuk membantuku bangun,

Seperti bagaimana aku membantumu berjalan sewaktu kecil,

Aku mohon jangan bosan denganku,

Ketika aku terus mengulang apa yang kukatakan seperti kaset rusak,

Aku harap kau terus mendengarkanku,

Tolong jangan bosan denganku

Apakah kamu ingat saat kamu masih kecil dan menginginkan sebuah balon?

Kamu mengulangi apa yang kamu mau sampai kamu mendapatkannya,

Maafkan juga bauku,

22 Istilah komprador digunakan oleh Amien Rais (2008) untuk menjelaskan korporatokrasi yang merupakan jejaring kekuasaan korporasi untuk mempertahankan kekuasaannya melalui antara lain elit politik, akademisi dan pemerintah. Mengenai pendidikan akuntansi yang diarahkan untuk memperteguh hegemoni korporasi juga dijabarkan oleh Mayper et al. (2005), Mulawarman (2008), Triyuwono (2010), dan Kamayanti (2012a, 2012b). 
Aku mohon jangan memaksaku untuk mandi

Orang tua mudah sakit, aku harap aku tidak terlihat kotor bagimu,

Apakah kamu ingat saat kamu masih kecil?

Aku selalu mengejar-ngejar kamu karena kamu tidak ingin mandi,

Dan jika kamu memiliki waktu, aku harap kita bisa bicara,

Bahkan untuk beberapa menit,

Aku selalu sendiri sepanjang waktu, dan tidak memiliki seorang pun untuk bicara.

Aku tahu kamu sibuk dengan pekerjaan,

Bahkan ketika kamu tidak tertarik pada ceritaku,

Aku mohon berikan aku waktu untuk bersamamu

Apakah kamu ingat ketika kamu masih kecil?

Aku mendengarkan apa yang kamu ceritakan tentang mainanmu

Ketika saatnya tiba dan aku hanya bisa terbaring sakit dan sakit,

Aku harap kamu memiliki kesabaran untuk merawatku,

MAAF,

Kalau aku sengaja mengompol atau membuat berantakan,

Aku harap kamu memiliki kesabaran untuk merawatku

selama beberapa saat terakhir kehidupanku,

Aku mungkin tidak akan bertahan lebih lama

Ketika waktu kematianku datang,

Aku harap kamu memegang tanganku dan memberi kekuatan untuk menghadapi kematian,

Dan jangan khawatir

Ketika aku bertemu Sang Pencipta

Aku akan berbisik kepadaNYA, untuk selalu memberikan berkah padamu,

Karena kamu mencintai Ibu dan Ayahmu,

Terima kasih atas perhatianmu, nak...

Kami mencintaimu

Dengan kasih yang berlimpah,

Ibu dan Ayah.

Selama pemutaran video tersebut, beberapa mahasiswa menangis. Setelah video tersebut usai, maka saya meminta mereka untuk mengambil secarik kertas dan alat tulis.

"Sekarang pertahankan rasa yang kalian dapatkan dari video tadi. Akuntansi adalah tentang pertanggungjawaban. Laporan Keuangan selain merupakan informasi untuk pengambilan keputusan, juga merupakan bentuk pertanggungjawaban. Video yang kita lihat juga tentang pertanggungjawaban antara orang tua kepada anak, anak kepada orang tua serta anak dan orang tua kepada Tuhan. Berdasarkan rasa ${ }^{23}$ yang telah kalian peroleh, tuliskan bagaimana kira-kira bentuk pertanggungjawaban dalam akuntansi sebaiknya menurut kalian? Saya berikan waktu 15 menit".

Setelah 15 menit, seluruh tulisan dikumpulkan dan saya memilih beberapa hasil tulisan mahasiswa. Mereka yang terpilih membacakan hasil refleksinya. Mahasiswa pertama adalah Nadiya. Ia menuliskan:

“...Orang tua saya menjadi sosok yang paling kuat dalam melindungi saya, tetapi saya sangat lemah mempertahankan apa yang sudah diberikan orang tua saya, saya sering tidak taat... Apabila saya hubungkan dengan akuntansi maka seberapa taat akuntansi menjaga pihak-

23 Deklarasi rektor-rektor seluruh Indonesia pada tanggal 4 Mei 2010 menegaskan antiplagiarisme serta perlunya kebutuhan untuk mengolah intelektualitas, rasa, jiwa, raga dan kekuatan diri. Latihan semacam ini dapat digunakan untuk mengolah rasa dan jiwa mahasiswa. 
pihak yag membutuhkan [hasil dari] akuntansi? Apakah akuntansi dapat memperkuat pihak yang lemah? Apakah akuntansi bisa bersikap ikhlas?"

Tulisan berikutnya dari Ria:

“...Orang tua yang baik adalah yang tulus mendidik kita dengan cara yang benar. Apabila akuntansi memberikan arti tersendiri ... apalagi ada unsur menolong... pasti akuntansi yang baik."

Giliran Hendra membacakan tulisannya:

“...Seharusnya seorang anak bertanggungjawab kepada orang tuanya sebagaimana kedua orang tua bertanggungjawab atas anak tersebut waktu kecil. Sedangkan.. dalam akuntansi sekarang, pemilik modal-lah yang menjadi tujuan pertanggungjawaban. Namun tidak ada timbal balik. Sungguh kejam.”

Fina yang mendapat giliran terakhir:

"Akuntansi dan pertanggungjawaban seperti kita dengan orang tua. Tidak ada pamrih di situ. Ada cinta kasih yang memang tulus kita berikan, tapi itu bukan paksaan, itu adalah dorongan hati nurani. Begitu pula akuntansi. Tidak perlu hukum, uang dan apapun itu yang 'wah' ... hanya butuh ketulusan untuk itu... Tidak ada yang memaksa memang, namun ketulusan cinta kasih itu adalah sebuah kebutuhan... Begitu pula akuntansi, pertanggungjawaban yang ada di dalamnya adalah kebutuhan hati, qalbu..."

Beberapa mahasiswa mendengarkan dan beberapa tertawa mendengar hasil tulisan mereka.

"Yang paling penting," saya memulai setelah mahasiswa membacakan tulisan mereka, "bahwa kalian semua telah berhasil mengungkapkan apa yang kalian inginkan dari akuntansi. Berdasarkan rasa, kalian telah mencipta. Berdasarkan rasa cinta dengan orang tua, kalian telah menunjukkan apa yang seharusnya menjadi tujuan pertanggungjawaban akuntansi atau bagaimana akuntansi sebaiknya bekerja. Bagaimana dengan cinta dengan alam? Apakah kira-kira kalian dapat mengungkapkan rasa dan menghubungkannya dengan akuntansi?" Setelah jeda sejenak saya melanjutkan, "Baik, mari kita coba. Bukankah kita saat ini berada di suatu lingkungan bagian dari alam semesta. Mari kita rasakan keberadaan alam kita dan keberadaan kita. Gunakan seluruh panca indera untuk merasakan semesta. Jika merasa perlu tutup mata kalian untuk mendengarkan alam lebih baik."

Selama 5 menit, kami diam. Beberapa mahasiswa memejamkan mata. Beberapa yang lain duduk santai sambil merenung, "Bagaimana, apa yang kalian dengarkan dari alam?"

"Bunyi mobil dan motor lalu lalang, Bu", sahut Hani diikuti tawa kelas.

"Alamnya jadi kendaraan ya?" sahut saya tersenyum, "Yang lain?"

"Saya bisa dengarkan bunyi burung di kejauhan," jawab Gagah.

"Hmm.. dari kejauhan ya? Apakah ini bentuk alam yang kalian idamkan atau bayangkan?" tanya saya lebih lanjut.

"Tidak juga sih, Bu. Pengennya ada pohon, bunyi sungai, kicauan burung," sahut Hani, "pasti rasanya tenang kalau dengar alam yang seperti itu."

"Jadi, ada rasa yang kalian dapatkan, dan ada rasa yang kalian inginkan. Berdasarkan itu silakan kalian tulis bagaimana akuntansi dihubungkan dengan rasa alam." Kelas jeda 10 menit lagi untuk merenung dan menulis. Akhirnya, setelah tulisan terkumpul, saya memilih dan meminta Nugi membacakan hasil tulisannya:

"Saya mencoba menyelam ke dalam titik kesadaran saya yang paling dalam...titik spiritual saya yang paling dalam...dan saya mendapatkan jawaban. Sebuah tumbuhan hanya akan mampu tumbuh menjadi sesuatu yang bermanfaat apabila dirawat dengan sungguh-sungguh, sama seperti akuntansi. Akuntansi di tangan yang tepat menjadi akuntansi syariah yang sarat dengan makna sosial, akuntansi di tangan kapitalis akan menjadi akuntansi kapitalis, akuntansi pasar bebas. Jika akuntansi adalah tumbuhan buahnya adalah laba. Buah anggur 
contohnya akan menjadi jus anggur, namun bisa menjadi memabukkan jika diolah oleh orang yang tidak tepat. Laba juga demikian...laba bisa digunakan untuk sosial, namun nyatanya hanya digunakan untuk menggemukkan perusahaan tanpa memperhatikan masyarakat sekitar. Pertanyaannya adalah... apakah kita orang yang tepat untuk 'menumbuhkan' akuntansi yang baik?'

Kelas bertepuk tangan setelah Nugie membacakan hasil tulisannya. "Bagus! Indah, bukan? Ini adalah langkah awal untuk mengembangkan. Segala bentuk cinta kepada orang tua, lingkungan, masyarakat dan negara harus merupakan perwujudan cinta kalian kepada Tuhan. Ya! Tentu perlu usaha dan terlebih cinta untuk menjadikannya nyata. Namun kalian baru saja menunjukkan bahwa kalian punya kemampuan untuk itu. Kalian adalah agen-agen peubah masa depan. Jangan pernah lupakan itu!"

\section{Simpulan dan Saran}

Proses dialogis memunculkan banyak kesadaran mahasiswa. Kesadaran ketuhanan atau spiritual muncul saat mahasiswa mendiskusikan pentingnya Tuhan secara teks maupun konteks dalam akuntansi. Kesadaran keIndonesiaan muncul saat mahasiswa secara kritis menginginkan jalan keluar bagi keterjebakan akuntansi. Kesadaran kebersamaan dan kemanusiaan muncul saat mahasiswa menggunakan rasa dan intuisi untuk menciptakan nilai dalam akuntansi. Kesadaran untuk berbuat adil muncul saat diskusi mengarah pada tujuan akuntansi konvensional, keberpihakan serta pembacaan terhadap dunia.

Walau demikian, keterbatasan penelitian ini terletak pada ketidakmampuannya untuk menangkap bahwa hasil penelitian yang merupakan pembentukan kesadaran yang utuh pada mahasiswa dapat terbawa pada diri mahasiswa secara permanen. Saya tidak bisa memastikan bahwa intervensi yang saya lakukan memang dapat memberikan hasil yang nyata, namun saya bisa memastikan bahwa proses dalam pendidikan dialogis ini memang nyata! Kemunculan-kemunculan kesadaran dalam proses pembelajaran ini nyata! Proses semacam ini dapat dilakukan pada semua jenis mata kuliah akuntansi walau dengan penekanan yang berbeda tergantung pada tingkat teknikalitas mata kuliah. Sebagai contoh, Kamayanti (2012a) pernah mencoba menglasifikasikan mata kuliah yang membutuhkan teknikalitas tinggi, analisis kritis yang tinggi dan emosi/intuitif yang tinggi. Proses pembelajaran inilah yang menjadi metodologi sekaligus hasil penelitian ini.

Bagaimana dengan kesadaran mahasiswa? Pada akhirnya kita perlu menyadari bahwa pendidikan merupakan indoktrinasi (Peterson, 2007), oleh karena itu jika dosen-dosen menerapkan pendidikan dialogis berkesadaran selama terus-menerus, apa yang dapat dilakukan oleh mahasiswa calon akuntan penerus bangsa bisa menjadi sangat tidak terbatas. Pendidikan akuntansi akan mampu menghasilkan akuntan yang memiliki kesadaran ketuhanan, kemanusiaan, keIndonesiaan, kebersamaan dan keadilan sosial; dan pada saat yang bersamaan mampu mengikuti arus globalisasi dengan sikap kritis yang menjaga integritas dan kemerdekaan bangsa Indonesia. Pertanyaannya bukan lagi, bisakah kita sebagai dosen menjadi pemicu kesadaran semacam ini, namun maukah?

\section{Daftar Pustaka}

Abeysekara, I. 2005. International Harmonisation of Accounting Imperialism- An Australian Perspective. Critical Management Studies Conference, Canada.

Al Attas, S.M.A.N. 1981. Islam dan Sekularisme. Translated. Penerbit Pustaka. Bandung.

Baskerville, R.L., dan A.T. Wood-Harper. 1996. A Critical Perspective on Action a Method for Information Systems Research. Journal of Information Technology. 11: 235-246.

Burrell, G. dan G. Morgan. 1979. Sociological Paradigms and Organizational Analysis: Elements of the sociology of corporate life. Ashgate Publishing Company. USA.

Bourdieu, P. 2010. Dominasi Maskulin. Terjemahan S.A Herwinarko. Jalasutra. Yogyakarta.

Capra, F. 2000. The Tao of Physics: Menyingkap Kesejajaran Metafisika Moderen dan Mistisisme Timur. Terjemahan. Percetakan Jalasutra. Yogyakarta.

Creswell, J.W. 2007. Qualitative Inquiry and Research Design: 'Choosing among Five Approaches. Sage Publication. USA. 
Chua, W.F. 1986. Radical Developments in Accounting Thought. The Accounting Review. Volume LXI No 4, October: 601-632.

Christie, N., B. Dyck, J. Morrill dan R. Stewart. 2004. Escaping The Materialistic- Individualistic Iron Cage: A Weberian Agenda for Alternative Radical Accounting. Fourth Asia Pacific Interdisciplinary Research in Accounting Conferences. 4-6 July.

Derks, H. 2008. Religion, Capitalism and The Rise of Double-entry Bookkeeping. Accounting, Business \& Financial History. 8 (2):187- 213.

Freire, P. 1972. Pedagogy of The Oppressed. Translated by Myra Bergman Ramos. Penguin Books. UK.

Freire, P. 2001. Pedagogi Hati. Translated. Penerbit Kanisius. Yogyakarta.

Funnell, W. dan R. Williams (ed). 2005. Critical and Historical Studies in Accounting. Australia: Pearson Education Australia.

Glasner, P.E. 1992. Sosiologi Sekularisasi: Suatu Kritik Konsep. PT. Tiara Wacana. Yogyakarta.

Held, D. 1980. Introduction to Critical Theory: Horkheimer to Habermas. University of California Press. Berkeley Los Angeles.

Hines, R.D. 1992. Accounting Filling the Negative Space. Accounting Organization and Society, 17(34):313- 341.

Hines, R. D. 1988. Financial Accounting: In Communicating Reality we construct Reality. Accounting Organization and Society. 13 (3): 251- 261.

Hertz, N. 2011. Penjajahan Kapitalisme: Runtuhnya Negara dan Virus Jahat Konsumerisme. Terjemahan. Penerbit Nuansa. Bandung.

Irvin, T. N. 1995. What's new about accounting education change? An historical perspective on the change movement. Accounting Horizon. 62.

James, Kieran. 2008. A Critical Theory and Postmodernist Approach to The Teaching of Accounting Theory. Critical Perspective on Accounting. 19: 643- 676.

Jonsonn, S. 2010. Interventionism-An Approach to the Future. Qualitative Reearch in Accounting and Manegement. 7(1):124-134.

Kamayanti, A. 2012a. Liberating Accounting Education: through Beauty and Beyond. LAMBERT Publishing Company. Germany.

Kamayanti, A. 2012b. Developing Conscious Accounting Educators: a Theatrical Perspective. Tesis. Universitas Brawijaya Malang.

Kirk, J. and M. L. Miller. 1986. Reliability and Validity in Qualitative Research. Sage Publications. USA.

Kirkeby, O. F. 2005. Loyalty and the sense of place. Editor: Laszlo Zsolnai. Spirituality and Ethics in Management. Kluwer Academic Publisher.

Kusuma, I.W. 2007. Pengadopsian International Financial Reporting Standards: Implikasi untuk Indonesia. Pidato Pengukuhan Jabatan Guru Besar pada Fakultas Ekonomi Universitas Gadjah Mada. 21 Mei. Yogyakarta.

Ludigdo, U. dan A. Kamayanti. 2012. Pancasila as Accountant Ethics Imperialism Liberator. World Journal of Social Sciences. 2 (6):159-168.

Mayper, A.G., R. J. Pavur, B. D. Merino dan W. Hoops. 2005. The Impact of Accounting Education on Ethical Values: An Institutional Perspective. Accounting and The Public Interest. 5:32-55.

Mulawarman A.D. 2008. Pendidikan Akuntansi Berbasis Cinta: Lepas dari Hegemoni Korporasi Menuju Pendidikan yang Memberdayakan dan Konsepsi Pembelajaran yang Melampaui. Ekuitas. 12 (2): 142-158.

Mulawarman, A.D. 2009. Akuntansi Syariah: Teori, Konsep dan Laporan Keuangan. E-Publishing. Jakarta.

Mulawarman, A.D. 2012. Accounting in the Madness Vortex of Neoliberal IFRS-IPSAS: A Criticism of IAS 41 and IPSAS 27 on Agriculture. International Conference on Critical Accounting. 23-24 April. New York.

Oakes, H. and A. Berry. 2009. Accounting Colonization: Three Case studies in Further Education. Critical Perspective on Accounting. 20: 343-378. 
Patton, M.Q. 2002. Qualitative Research and Evaluation Methods. Third Edition. Sage Publication. United States of America.

Peterson, B.A. 2007. Holding Teacher Accountable for Indoctrination: A Reexamination of I.A. Snook's Notion of Intent. Philosophy of Education. 298-305.

Rais, MA. 2008. Selamatkan Indonesia: Agenda Mendesak Bangsa. PPSK Press. Yogyakarta.

Ratnatunga, J. 2010. The Accounting Delusion: Faith and Trust in Financial Reporting. Presented at The Third International Symposium and the Second Doctoral Colloquium, Bali, 27-29 November.

Setiawan, A.R dan A. Kamayanti. 2012. Mendobrak Reproduksi Dominasi Maskulinitas dalam Pendidikan Akuntansi: Internaliasasi Pancasila dalam Pembelajaran Fraud Accounting. Proceeding Konferensi Nasional Pendidikan Akuntansi Indonesia. 18-20 April.

Sukoharsono, E.G. 2011. Green Accounting to be a Serious Business of Accounting Discipline: An Imaginary Neo-Postmordenist Dialogue. Simposium Nasional Akuntansi 14.

Triyuwono, I. 2006. Perspektif, Metodologi dan Teori Akuntansi Syariah. PT. RajaGrafindo Persada. Jakarta.

Triyuwono, I. 2010. Mata Ketiga: Sé Laén, Sang Pembebas Sistem Pendidikan Tinggi Akuntansi. Jurnal Akuntansi Multiparadigma. 1(1): 1-18.

Truan, F. and H. Hughes. 1999. Tradition or Enlightenment: Philosophical Choice in Accounting Academia. Journal of Accounting Education. 17: 23-34.

Undang Undang Dasar (UUD) Republik Indonesia tahun 1945. 